\title{
Involvement of TRPV2 Activation in Intestinal Movement through Nitric Oxide Production in Mice
}

\author{
Hiroshi Mihara, ${ }^{1,2}$ Ammar Boudaka, ${ }^{1}$ Koji Shibasaki, ${ }^{1,3,4}$ Akihiro Yamanaka, ${ }^{1,3}$ Toshiro Sugiyama, ${ }^{2}$ \\ and Makoto Tominaga ${ }^{1,3}$ \\ ${ }^{1}$ Division of Cell Signaling, Okazaki Institute for Integrative Bioscience (National Institute for Physiological Sciences), National Institutes of Natural \\ Sciences, Okazaki 444-8787, Japan, ${ }^{2}$ Department of Gastroenterology, Graduate School of Medicine and Pharmaceutical Sciences, University of Toyama, \\ Toyama 930-8555, Japan, ${ }^{3}$ Department of Physiological Sciences, The Graduate University for Advanced Studies, Okazaki 444-8585, Japan, and \\ ${ }^{4}$ Department of Molecular and Cellular Neurology, Gunma University Graduate School of Medicine, Maebashi 371-8511, Japan
}

Transient receptor potential channel vanilloid 2 (TRPV2) can detect various stimuli such as temperature $\left(>52^{\circ} \mathrm{C}\right.$ ), stretch, and chemicals, including 2-aminoethoxydiphenyl borate, probenecid, and lysophospholipids. Although expressed in many tissues, including sensory and motor neurons, TRPV2 expression and function in the gastrointestinal tract is poorly understood. Here, we show TRPV2 expression in the murine intestine and its involvement in intestinal function. Almost all mouse intestinal intrinsic sensory and inhibitory motor neurons, both cell bodies and nerve fibers, showed TRPV2 immunoreactivity. Several known TRPV2 activators increased cytosolic $\mathrm{Ca}^{2+}$ concentrations and evoked TRPV2-like current responses in dissociated myenteric neurons. Interestingly, mechanical stimuli activated inward currents in a strength-dependent manner, which were inhibited by a TRPV2 inhibitor tranilast. TRPV2 activation in isolated intestine inhibited spontaneous circular muscle contraction, which did not occur in the presence of the TRPV2 antagonist, tetrodotoxin or nitro oxide (NO) synthase pathway inhibitors. Also, increased intestinal NO production was observed in response to a TRPV2 agonist, and gastrointestinal transit in vivo was accelerated by TRPV2 agonists or an NO donor. In conclusion, TRPV2 may contribute to intestinal motility through NO production, and TRPV2 is a promising target for controlling intestinal movement.

\section{Introduction}

The intestine contains intrinsic primary afferent neurons (IPANs) and a local reflex system (including interneurons, excitatory and inhibitory motor neurons) that play important roles in controlling bowel movement (Furness et al., 2004a; Furness, 2008). Interestingly, many IPANs and some uniaxonal neurons (mainly excitatory and inhibitory motor neurons) appear to be mechanosensitive and activated by muscle contractions in guinea pig intestine (Kunze et al., 1998, 1999). Acetylcholine (ACh) and nitric oxide (NO) are dominant excitatory and inhibitory neurotransmitters, respectively (Harrison and McSwiney, 1936; Rand, 1992), and abnormal NO production or release has been implicated in functional gastrointestinal disorders (Takahashi, 2003).

\footnotetext{
Received Aug. 24, 2010; revised Sept. 23, 2010; accepted 0ct. 1, 2010.

This work was supported by grants from the Ministry of Education, Culture, Sports, Science and Technology in Japan (M.T.). We thank A. Kuwabara (University of Shizuoka), S. Karaki (University of Shizuoka), H. Suzuki (Nagoya City University), H. Hashitani (Nagoya City University), and Y. Kito (Nagoya City University) for help in intestinal tissue preparation and discussions, E. Ashitaka (Kansai Medical University) and T. Mohri (National Institute for Physiological Sciences) for suggestions regarding NO detection, P. C. Emson (The Babraham Institute), J. Furness (University of Melbourne), and Kissei Pharmaceutical Co. for their generous gifts of antibodies or chemical, M. Kadowaki (University of Toyama) and S. Oda (University of Toyama) for discussions, and H. Inada (Harvard University), T. Sokabe (National Institute for Physiological Sciences), and K. Uchida (National Institute for Physiological Sciences) for technical assistance.

The authors declared no competing financial interests.

Correspondence should be addressed to Dr. M. Tominaga, Division of Cell Signaling, Okazaki Institute for Integrative Bioscience, National Institutes of Natural Sciences, 0kazaki, Aichi 444-8787, Japan. E-mail: tominaga@ nips.ac.jp.

DOI:10.1523/JNEUROSCI.4426-10.2010

Copyright $\odot 2010$ the authors $\quad 0270-6474 / 10 / 3016536-09 \$ 15.00 / 0$
}

However, the underlying molecular and cellular mechanisms are poorly understood.

Transient receptor potential vanilloid 2 (TRPV2) was originally isolated as a molecule sensitive to temperatures above $52^{\circ} \mathrm{C}$ (Caterina et al., 1999) but has since been shown to be sensitive to some chemicals [e.g., 2-aminoethoxydiphenyl borate (2-APB), probenecid (Pro), and lysophospholipids] and mechanical stimuli (Muraki et al., 2003; Hu et al., 2004; Bang et al., 2007; Monet et al., 2009; Shibasaki et al., 2010). TRPV2 expression has been observed in TRPV1-negative medium- to large-diameter neurons of the rat dorsal root and trigeminal ganglia and possibly in thinly myelinated nociceptors (Caterina et al., 1999; Lewinter et al., 2008). However, TRPV2 mRNA or immunoreactivity has also been detected in the brain, autonomic ganglia, spinal cord, skeletal and vascular myocytes, visceral organs (including the intestine, pancreas, spleen, and bladder), and blood cells (Caterina et al., 1999; Ichikawa and Sugimoto, 2001; Muraki et al., 2003; Kashiba et al., 2004; Lewinter et al., 2004; Inada et al., 2006; Lewinter et al., 2008; Hisanaga et al., 2009; Zanou et al., 2009; Link et al., 2010). TRPV2 expression may also be involved in the migration and proliferation of cancer cells (Caprodossi et al., 2008; Monet et al., 2010), and TRPV2-positive neurons observed in the rat myenteric plexus may be IPANs (Kashiba et al., 2004). Mechanosensitivity of TRPV2 was first reported in cardiac myocytes (Muraki et al., 2003), and we have recently reported its expression and mechanosensitivity in developing sensory and motor neurons (Shibasaki et al., 2010). 
Table 1. Characteristics of primary antisera

\begin{tabular}{llll}
\hline Tissue antigen & Host & Dilution & Source \\
\hline TRPV2 & Rabbit & $1: 200$ & TransGenic \\
PGP9.5 & Mouse & $1: 200$ & Serotec, monoclonal antibody (31A3) \\
GFAP & Mouse & $1: 100$ & Sigma, monoclonal antibody (GA5) \\
KIT & Rat & $1: 50$ & BD Biosciences \\
Neuronal N0S & Sheep & $1: 2000$ & P.C. Emson (Williamson et al., 1996) \\
CGRP & Sheep & $1: 1000$ & J. Furness (Qu et al., 2008) \\
NF145 & Mouse & $1: 300$ & Millipore, monoclonal antibody (MAB1621)
\end{tabular}

Table 2. Secondary antibodies used for immunohistochemistry

\begin{tabular}{lll}
\hline Antibody label & Dilution & Source \\
\hline Goat anti-rabbit IgG-Alexa Fluor 488 & $1: 1500$ & Invitrogen \\
Goat anti-rabbit IgG-Alexa Fluor 635 & $1: 1500$ & Invitrogen \\
Donkey anti-sheep IgG-Alexa Fluor 546 & $1: 1500$ & Invitrogen \\
Goat anti-mouse IgG-Alexa Fluor 488 & $1: 1500$ & Invitrogen \\
Donkey anti-sheep IgG-Alexa Fluor 488 & $1: 1500$ & Invitrogen \\
\hline
\end{tabular}

However, the precise distribution of TRPV2 expression in intestinal neurons and its functional significance remain unknown. In this study, we demonstrate that TRPV2-positive inhibitory motor neurons and IPANs may contribute to the inhibitory modulation of intestinal movement.

\section{Materials and Methods}

Animals. Male C57BL/6 (5-12 weeks old; SLC) and ChAT-eGFP (choline acetyltransferase-enhanced green fluorescent protein) [5-8 weeks old; The Jackson Laboratory (Tallini et al., 2006)] mice were used. ChAT-eGFP was used as a marker for IPANs and excitatory motor neurons. Mice were housed in a controlled environment $(12 \mathrm{~h} \mathrm{light/dark}$ cycle; room temperature, $22-24^{\circ} \mathrm{C} ; 50-60 \%$ relative humidity) with access to food and water ad libitum. All procedures involving the care and use of animals were approved by The Institutional Animal Care and Use Committee of National Institutes of Natural Sciences and performed in accordance with the Guide for the Care and Use of Laboratory Animals (National Institutes of Health publication number 85-23, revised 1985).

Reverse transcription-PCR analysis. To examine TRPV2 expression in the murine gut, total RNAs $(1 \mu \mathrm{g})$ isolated from whole intestine, wholemount preparations of longitudinal muscle with myenteric plexus (LMMP) of distal intestine, and primary myenteric culture cells (MCC) were used for reverse transcription with Superscript III first-strand synthesis system for reverse transcription (RT)-PCR (Invitrogen). PCR was performed using rTaq DNA polymerase (TaKaRa) in an iCycler (BioRad) with specific primer sets (supplemental Table 1, available at www. jneurosci.org as supplemental material) for several TRP channels, including TRPV2 (Inada et al., 2006) and the neural marker protein gene product 9.5 (PGP9.5). PCR conditions used were as follows: 1 cycle at $94^{\circ} \mathrm{C}$ for $2 \mathrm{~min} ; 40$ cycles at $94^{\circ} \mathrm{C}$ for $10 \mathrm{~s}, 55^{\circ} \mathrm{C}$ for $10 \mathrm{~s}$, and $72^{\circ} \mathrm{C}$ for $30 \mathrm{~s}$; and 1 cycle at $72^{\circ} \mathrm{C}$ for $2 \mathrm{~min}$.

Immunohistochemistry. Immunohistochemical methods were modified from previous reports (Ward et al., 2003; Furness et al., 2004b; Qu et al., 2008). All experiments were repeated on specimens from at least three mice. Antibody information is summarized in Tables 1 and 2.

For LMMP preparation, male mice $(8-12$ weeks of age) were killed by cervical dislocation after light diethyl ether anesthesia. The gastrointestinal tract from the duodenum to distal colon was removed, the small intestine was opened along the mesenteric border, and the luminal contents was washed with Tyrode's solution. Opened segments were pinned onto the base of an elastomer dish with the mucosal side facing downward for fixation with $4 \%$ paraformaldehyde in PBS $(0.15 \mathrm{M} \mathrm{NaCl}$ in 0.01 M sodium phosphate buffer, $\mathrm{pH} 7.2$ ) at $4^{\circ} \mathrm{C}$ for $1 \mathrm{~h}$. The mucosa, submucosa, and circular muscle were removed, and LMMPs were prepared. Preparations were cleared of fixative with PBS plus $0.3 \%$ Triton X-100 $(0.3 \%$ PBS-T) (three washes, 5 min each). Nonspecific antibody binding was reduced by incubation with $3 \%$ bovine serum albumin (Sigma) in

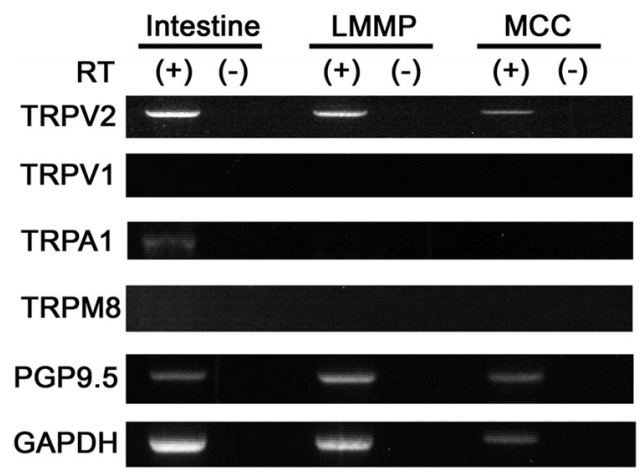

Figure 1. Expression of TRPV2 genes in isolated whole intestine, LMMP, and MCC. mRNAs of TRPV2, TRPV1, TRPA1, TRPM8, PGP9.5, and glyceraldehyde-3-phosphate dehydrogenase $(G A P D H)$ were examined with $(+)$ and without $(-) R T$ reaction. Expected sizes of the amplified fragments of TRPV2, TRPV1, TRPA1, TRPM8, PGP9.5, and GAPDH are 552, 548, 577, 412, 413, and 545 bp, respectively.

$0.3 \%$ PBS-T for $1 \mathrm{~h}$ at room temperature before exposure to rabbit antiTRPV2 antibody and several specific cell type markers [PGP9.5, glial fibrillary acidic protein (GFAP), KIT (CD117)] or different enteric neuron class markers. Anti-neuronal nitric oxide synthase (nNOS) and anticalcitonin gene-related peptide (CGRP) antibodies were generous gifts from Dr. P. C. Emson (The Babraham Institute, Cambridge, UK) and Dr. J. B. Furness (University of Melbourne, VIC, Australia), respectively. An anti-rat TRPV2 antibody was made by our laboratory and verified by Western blot. LMMP preparations were incubated with primary antibodies at $4^{\circ} \mathrm{C}$ overnight and then washed (three times, 10 min each) in $0.3 \%$ PBS-T before incubation with secondary antibodies at room temperature for $1 \mathrm{~h}$. Preparations were then washed (three times, $10 \mathrm{~min}$ each) in PBS and mounted on glass slides using a commercially available mounting medium (Diagnostic BioSystems). To visualize cellular CGRP as an IPAN marker, tissues were incubated in oxygenized DMEM containing colchicine before fixation as described previously $(\mathrm{Qu}$ et al., 2008).

For section preparation, three mice were anesthetized with diethyl ether and perfused through the heart with the same fixative as used for immersion fixation. Intestinal tissues were removed and further fixed at $4^{\circ} \mathrm{C}$ for $6 \mathrm{~h}$. Tissues were washed in PBS (three times, 15 min each), placed in PBS-sucrose (PBS containing $20 \%$ sucrose), and stored at $4{ }^{\circ} \mathrm{C}$ overnight. Next, small intestinal segments were embedded in OCT compound (Tissue Tek), and 14- $\mu \mathrm{m}$-thick sections were collected onto slides and dried at room temperature for $1 \mathrm{~h}$. Sections were then incubated in primary and secondary antibodies as described above. Preparations were analyzed using a fluorescent microscope and a confocal laser scanning microscope (LSM 510; Carl Zeiss).

Primary culture of myenteric neurons. The method was modified from a previous report (Bian and Galligan, 2007). Male wild-type (WT) and ChATBAC-eGFP mice (5 weeks of age) were killed by cervical dislocation after light diethyl ether anesthesia. The entire length of small intestine was placed in cold $\left(4^{\circ} \mathrm{C}\right)$ PBS. LMMP was stripped free and cut into $5 \mathrm{~mm}$ pieces. Tissues were divided into two aliquots, with each aliquot incubated in $1 \mathrm{ml}$ of trypsin solution (Invitrogen) at $37^{\circ} \mathrm{C}$ for $15 \mathrm{~min}$. Tissues were then gently triturated 30 times using a Pasteur pipette and centrifuged at $900 \times g$ for $5 \mathrm{~min}$. Pellets were resuspended and incubated $\left(15 \mathrm{~min}, 37^{\circ} \mathrm{C}\right)$ in Tyrode's solution containing $1 \mathrm{mg} / \mathrm{ml}$ collagenase (Sigma). Suspensions were triturated again 30 times and centrifuged at $900 \times g$ for 5 min after cell strainer (Falcon; BD Biosciences Discovery Labware) filtering. Pellets were suspended in MEM containing $10 \%$ fetal bovine serum, NGF (100 ng/ml), penicillin (100 U/ml), and streptomy$\operatorname{cin}(50 \mu \mathrm{g} / \mathrm{ml})$. Cells were plated on glass coverslips coated with poly-Dlysine $(50 \mu \mathrm{g} / \mathrm{ml}$ for $2 \mathrm{~h})$ and incubated at $37^{\circ} \mathrm{C}$ with $5 \% \mathrm{CO}_{2}$.

In vitro electroporation. Dominant-negative (DN) TRPV2 plasmid DNA (Nagasawa et al., 2007) or pcDNA3.1 vector (final concentration, 5 $\mu \mathrm{g} / 100 \mu \mathrm{l}$ ) along with Discosoma Red cDNA was electroporated using a pulse generator Neon (Invitrogen) into myenteric neurons isolated from ChAT-eGFP mice ( 5 weeks of age, both sexes). 
$\mathrm{Ca}^{2+}$ imaging. Fura-2 fluorescence was measured in cultured myenteric cells using standard bath solution (in mm: $140 \mathrm{NaCl}, 5 \mathrm{KCl}, 2$ $\mathrm{MgCl}_{2}, 2 \mathrm{CaCl}_{2}, 10$ HEPES, and 10 glucose at $\mathrm{pH}$ 7.4, adjusted with $\mathrm{NaOH}$ ). Ratio of fluorescence intensities obtained with fura-2 emissions at 340 and $380 \mathrm{~nm}$ were calculated. TRPV2 agonists 2-APB, probenecid, and lysophosphatidylcholine (LPC) (all from Sigma) and TRPV2 antagonists [a broad TRP channel blocker, ruthenium red (RR), and a TRPV2specific antagonist, tranilast (Tra) (Hisanaga et al., 2009) (provided by Kissei)] were used. To identify myenteric neurons, high-potassium (50 mM) solution was applied. All experiments were performed at room temperature $\left(25^{\circ} \mathrm{C}\right)$. Neuronal sensitivity to the various compounds (responders) was defined as an increase in 340/ 380 ratio $>0.25$, except for in vitro electroporation studies in which a ratio increase $>0.1$ was used.

Electrophysiology. The standard bath solution for the patch-clamp experiments was the same as that used in the $\mathrm{Ca}^{2+}$-imaging experiments. Pipette solution for whole-cell recordings contained $140 \mathrm{~mm} \mathrm{CsCl,} 5 \mathrm{~mm}$ EGTA, and 10 mM HEPES, pH 7.4. Mechanical stimulus was achieved by applying positive and negative pressures $\left(3-10 \mathrm{~cm} \mathrm{H}_{2} \mathrm{O}\right)$ to the pipette. Data from whole-cell voltage-clamp recordings were sampled at $10 \mathrm{kHz}$ and filtered at $5 \mathrm{kHz}$ for analysis (Axon 200B amplifier with pClamp software; Molecular Devices). Voltage ramp pulses from -100 to $+100 \mathrm{mV}$ (500 ms) were applied every 4-6 s to generate an currentvoltage $(I-V)$ curve. All the experiments were performed at room temperature $\left(25^{\circ} \mathrm{C}\right)$.

Tension recording of isolated intestines. Spontaneous intestinal contractions of circular muscle were recorded as described previously (Penuelas et al., 2007; Boudaka et al., 2009). Briefly, 8 - to 12 -week-old male WT mice were killed by cervical dislocation. Whole-intestinal segments were removed and kept in Tyrode's solution bubbled with 95\% $\mathrm{O}_{2} / 5 \% \mathrm{CO}_{2}$. Lengths of $\sim 1.0 \mathrm{~cm}$ of cylindrical intestine were placed under a $0.5 \mathrm{~g}$ load in a 10 $\mathrm{ml}$ organ bath filled with Tyrode's solution at $30-33^{\circ} \mathrm{C}$ and continuously bubbled with $95 \%$ $\mathrm{O}_{2} / 5 \% \mathrm{CO}_{2}$. Spontaneous contractions were monitored using an isotonic transducer. After tissue recovery for $30 \mathrm{~min}$, responses to TRPV2 agonists [probenecid, LPC, and lysophosphatidylinositol (LPI) (Sigma)] and an NO donor [sodium nitroprusside (SNP) (Wako)] were examined. Lysophosphatidic acid (LPA) (Sigma) was used as a negative control (Monet et al., 2009). Tetrodotoxin (TTX), $N^{\mathrm{G}}$-nitro-L-arginine methyl ester, hydrochloride (L-NAME), $N^{\omega_{-}}$

nitro-L-arginine (L-NNA) (an NO scavenger), hemoglobin ( $\mathrm{Hb}$ ), and the guanylate cyclase inhibitor methylene blue (all from Sigma, except for TTX, which is from Sankyo) were used as 10 min pretreatments before agonist application. Each response was expressed as the ratio of late values (mean of contractile amplitudes at $2-3$ or $5-6 \mathrm{~min}$ ) to basal values (1 min) using PowerLab Chart5 version 5.1 (AD Instruments).

Measurement of NO release (Griess assay). The method was modified from previous reports (Korenaga et al., 2006; Wehner et al., 2009). Whole-intestine tissues were washed and kept in Tyrode's solution bubbled with $95 \% \mathrm{O}_{2} / 5 \% \mathrm{CO}_{2}$. Small segments $(0.5 \mathrm{~mm}$ each) were trans-

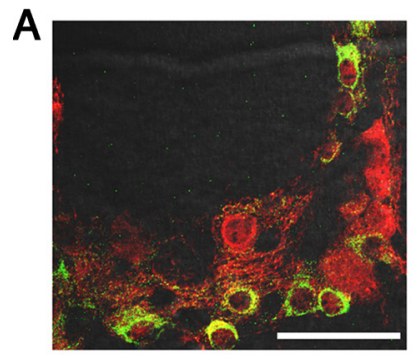

PGP9. 5/TRPV2

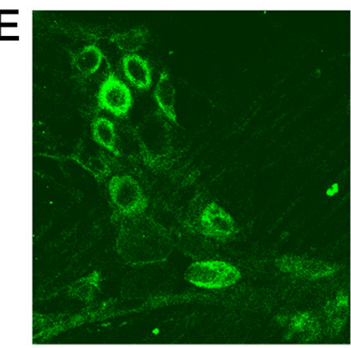

TRPV2

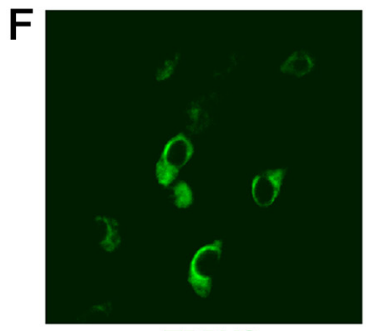

TRPV2

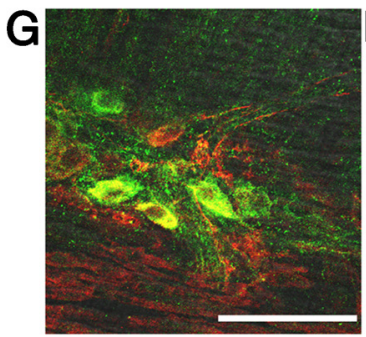

NF145/TRPV2
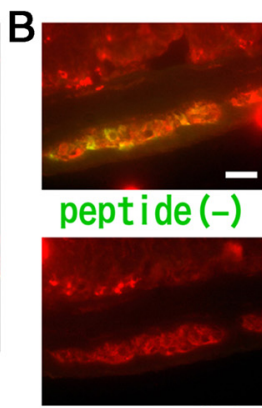

peptide (+)

PGP9. 5/TRPV2

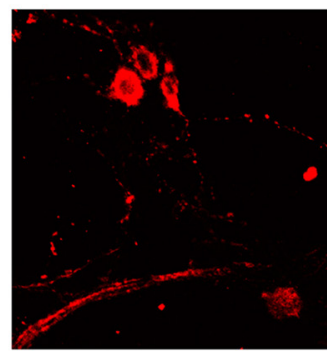

nNOS

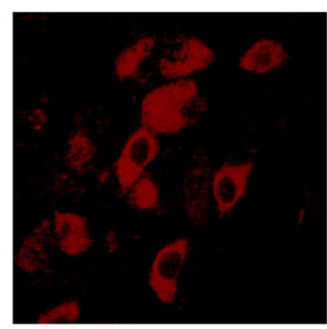

CGRP

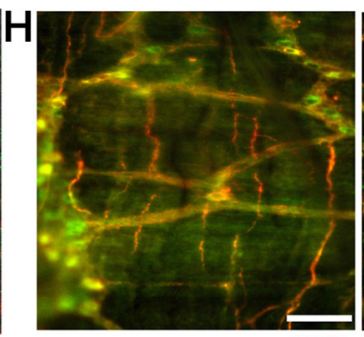

nNOS/TRPV2

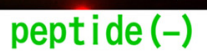

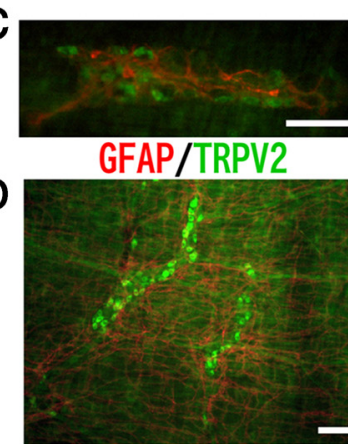

KIT/TRPV2

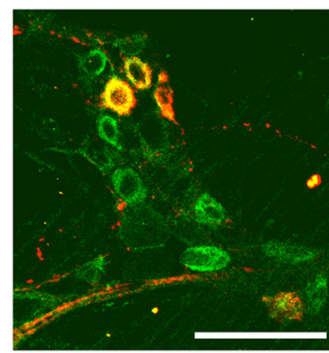

Merge

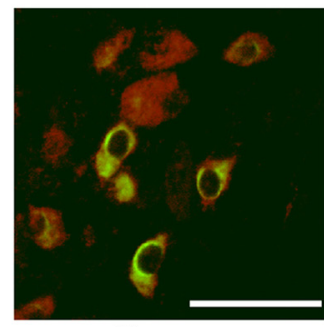

Merge

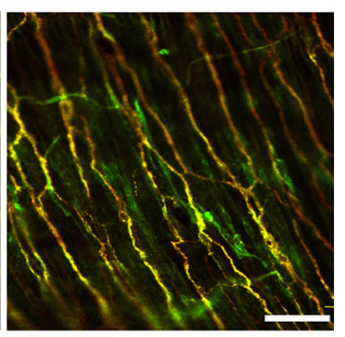

Figure 2. TRPV2 immunoreactivity in murine myenteric plexus neurons. $\boldsymbol{A}, \mathrm{TRPV} 2$-immunoreactive cells (green) were observed in PGP9.5-immunoreactive myenteric neurons (red). $\boldsymbol{B}$, TRPV2 immunoreactivity in the same section was abolished with antigenic TRPV2 peptide. $\boldsymbol{C}, \boldsymbol{D}$, GFAP (red in $\boldsymbol{C}$ ) or KIT (red in $\boldsymbol{D}$ ) were not coexpressed with TRPV2 (green). $\boldsymbol{E}$, Staining of TRPV2 (left, green) preparation. Merged images (far right) indicate coexpression of nNOS $(\boldsymbol{E})$ or CGRP $(\boldsymbol{F})$ in TRPV2-positive cells. $\mathbf{G}$, Costaining of NF145 (red) and TRPV2 (green) in the LMMP preparation. $\boldsymbol{H}$, Merged images of TRPV2 (green)- and nNOS (red)-IR nerve fibers in the LMMP preparation (left, plexus area; right, muscle area). All nNOS-IR fibers show TRPV2 immunoreactivity, and some TRPV2-IR fibers show no nNOS-immunoreactivity. Scale bars, $50 \mu \mathrm{m}$.

ferred to microtubes containing $0.5 \mathrm{ml}$ of Tyrode's solution with or without probenecid. Response to $10 \mu \mathrm{M}$ nicotine was used as a positive control (Patel et al., 2008). After $30 \mathrm{~min}$ incubation at $30^{\circ} \mathrm{C}$, microtubes were centrifuged at $132,000 \mathrm{rpm}$ at $4^{\circ} \mathrm{C}$ for $20 \mathrm{~min}$. Tissues were removed and dried overnight to measure dry weight. Supernatants were centrifuged with Amicon Ultra-4 Centrifugal Filter Units with Ultracel-1 membranes $\left(7000 \times g, 4^{\circ} \mathrm{C}, 20 \mathrm{~min}\right)$ to remove proteins. $\mathrm{NO}_{2}$ and $\mathrm{NO}_{3}$ concentrations were detected with an $\mathrm{NO}_{2} / \mathrm{NO}_{3}$ Assay kit (DOJINDO) using a fluoromicroplate reader (Hitachi) with excitation at $365 \mathrm{~nm}$ and emission at $450 \mathrm{~nm}$ under basic $\mathrm{pH}$. NO concentrations were determined 
A

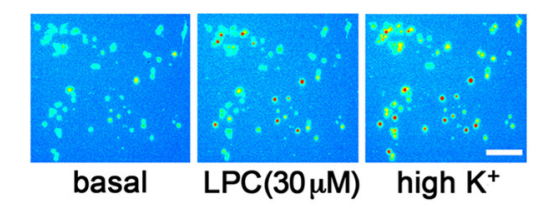

B

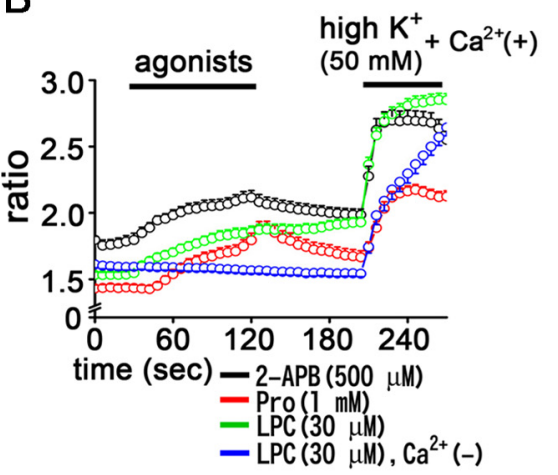

C

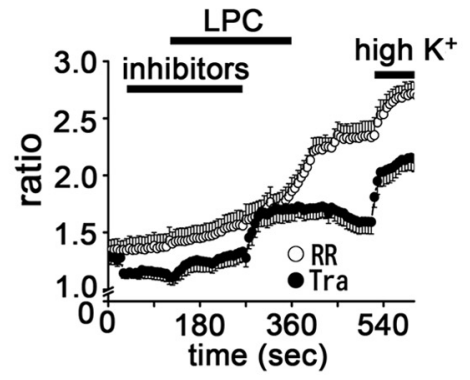

$\mathrm{D}$

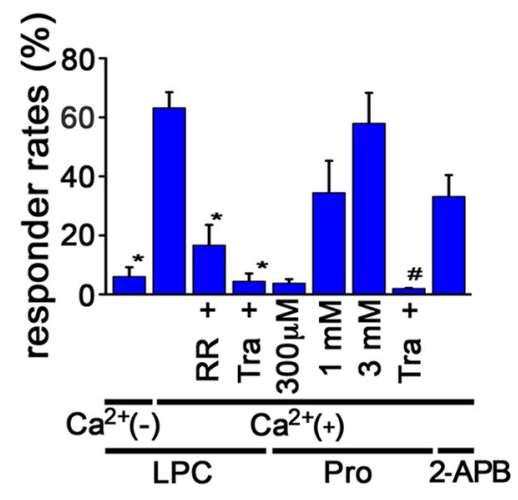

E

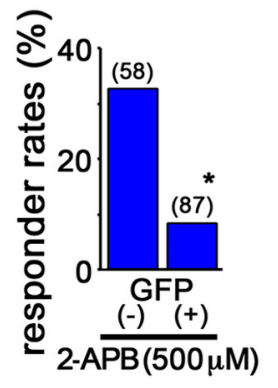

$\mathrm{F}$

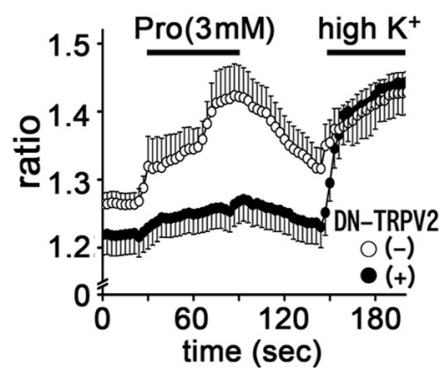

G

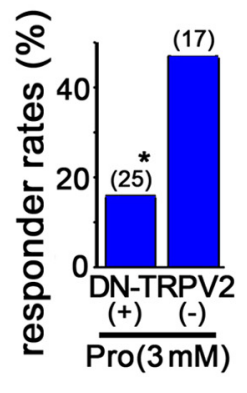

Figure 3. TRPV2-mediated cytosolic $\mathrm{Ca}^{2+}$ increase in myenteric culture neurons. $A$, Changes in cytosolic $\mathrm{Ca}^{2+}$ concentration $\left(\left[\mathrm{Ca}^{2+}\right]_{\mathrm{j}}\right)$ indicated by the fura-2 ratio, with pseudocolor expression, in response to $30 \mu \mathrm{M} \mathrm{LPC}$ and $50 \mathrm{~mm}$ high $\mathrm{K}^{+}$solution in primary myenteric culture neurons. Scale bar, $50 \mu \mathrm{m}$. B, Traces of $\left[\mathrm{Ca}^{2+}\right]_{\mathrm{i}}$ changes (340/380 ratio) in response to three TRPV2 agonists (2-APB, Pro, and LPC) in mouse myenteric culture neurons (mean + SEM). Bars indicate the period of chemical application. $\mathrm{LPC}$-induced $\left[\mathrm{Ca}^{2+}\right]_{\mathrm{i}}$ increase is not observed in the absence of extracellular $\mathrm{Ca}^{2+}\left[\mathrm{LPC}_{1} \mathrm{Ca}^{2+}(-)\right.$, mean $\left.\pm \mathrm{SEM}\right]$. Data are from 27-111 cells. C, Traces of $\left[\mathrm{Ca}^{2+}\right]_{\mathrm{i}}$ changes in response to LPC with two TRPV2 inhibitors (RR at $10 \mu \mathrm{m}$ and Tra at $75 \mu \mathrm{m}$ ) in mouse myenteric culture neurons (mean \pm SEM). Data are from 10 cells. $D$, Percentage of responders (see Materials and Methods) to TRPV2 agonists (LPC at $30 \mu \mathrm{m}$, Pro at $1 \mathrm{~mm}$, and 2-APB at $500 \mu \mathrm{m}$ ) with or without TRPV2 inhibitors (RR at $10 \mu \mathrm{m}$ and Tra at 75 $\mu \mathrm{M})$ in the presence $\left[\mathrm{Ca}^{2+}(+)\right]$ or absence $\left[\mathrm{Ca}^{2+}(-)\right]$ of extracellular $\mathrm{Ca}^{2+}$. Responder rates in cells treated with LPC in $\mathrm{Ca}^{2+}(-)(6.0 \pm 3.2 \%, n=85)$ and cells treated with $\mathrm{RR}(16.7 \pm 6.9 \%, n=51)$ or $\operatorname{Tra}(4.4 \pm 2.7 \%, n=133)$ in $\mathrm{Ca}^{2+}(+)$ are

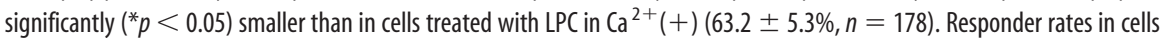
treated with Pro in the presence of $\operatorname{Tra}(2.0 \pm 0.2 \%, n=155)$ are significantly $\left({ }^{\#} p<0.05\right)$ smaller than in cells treated with Pro $(3.7 \pm 1.4 \%, n=98 ; 34.4 \pm 10.8 \%, n=167 ; 57.9 \pm 10.4 \%, n=70$ for $300 \mu \mathrm{m}, 1 \mathrm{~mm}$, and $3 \mathrm{~mm}$, respectively). $\boldsymbol{E}$, Responder rates in cells responding to 2 -APB $(500 \mu \mathrm{M})$ with $(+)$ GFP expression $(8.4 \%)$ are significantly $\left({ }^{* *} p<0.01\right)$ smaller than in cells without (-) GFP expression (32.7\%). Numbers in parentheses indicate cells examined. Data are from 12 samples. $\boldsymbol{F}$, Traces of $\left[\mathrm{Ca}^{2+}\right]_{\mathrm{i}}$ changes in response to $3 \mathrm{~mm}$ Pro in mouse myenteric culture neurons (mean $\pm \mathrm{SEM}$ ) without $(-; n=17)$ or with $(+$; $n=25)$ expression of DN-TRPV2. G, Responder rate in cells responding to Pro $(3 \mathrm{~mm})$ with expression of DN-TRPV2 $(+; 16.0 \%)$ is significantly $\left({ }^{*} p<0.05\right)$ smaller than in cells without DN-TRPV2 expression $(-; 53.3 \%)$. Numbers in parentheses indicate number of cells examined.

by interpolation of a standard NaNO concentration curve against fluorescence intensity. Total nitrite production was calculated as amount per gram intestinal tissue.

Gastrointestinal tract transit assay. The gastrointestinal tract transit assay was performed as described previously (Firpo et al., 2005) using WT 8- to 12-week-old male mice. Briefly, mice were fasted for $14 \mathrm{~h}$ with water available ad libitum, and then $5 \mathrm{mg} / \mathrm{kg}(200 \mu \mathrm{l})$ of a test meal containing phenol red along with the TRPV2 agonists $10 \mu \mathrm{M}$ SNP or vehicle only was administered into the stomach using a feeding needle.
Thirty minutes later, mice were killed by cervical dislocation, the gastrointestinal tract was removed, and then the small intestine was divided into four equal-length pieces. Stomach and intestine tissues were minced, transferred to $10 \mathrm{ml}$ of $0.1 \mathrm{~N} \mathrm{NaOH}$, and homogenized at room temperature for $1 \mathrm{~h}$. Phenol red was not detected in any colorectal samples. Supernatant aliquots $(1 \mathrm{ml})$ were transferred into 0.1 $\mathrm{ml}$ of $20 \%$ trichloroacetic acid solution to precipitate proteins and centrifuged at $3000 \mathrm{rpm}$ for $20 \mathrm{~min}$, and $250 \mu \mathrm{l}$ of the supernatant was added to $1 \mathrm{ml}$ of $0.5 \mathrm{~N} \mathrm{NaOH}$ to develop the maximum color intensity. Phenol red concentration was measured by absorbance at $560 \mathrm{~nm}$ using a spectrophotometer and expressed as mean \pm SEM in each group.

Data analysis. $\mathrm{Ca}^{2+}$ imaging, patch-clamp recordings, tension recordings, Griess assay, and in vivo study values were calculated as means \pm SEM from three or more independent experiments. Student's $t$ test, nonparametric Bonferroni's-type multiple comparison, or $\chi^{2}$ test was used. $p<0.05$ was considered statistically significant.

\section{Results}

Expression of TRPV2 mRNA in intestine myenteric neurons

Because TRPV2 was shown to be expressed in the rat myenteric plexus and to have some mechanosensitivity (Muraki et al., 2003; Kashiba et al., 2004; Shibasaki et al., 2010), we examined TRPV2 expression in the small intestine. mRNA expression of TRPV2 and the control PGP9.5 (a neuron marker) was detected in whole small intestine, longitudinal muscle with myenteric plexus (LMMP), and intestinal MCC (Fig. 1). TRPV1 and transient receptor potential melastatin 8 (TRPM8) mRNA were not detected, although TRP ankyrin 1 (TRPA1) mRNA was detected in the whole intestine but not in LMMP or MCC, which is consistent with the observation of functional TRPA1 expression in enterochromaffin cells and the involvement of TRPA1 in murine intestinal contractions (Nozawa et al., 2009).

\section{Expression of TRPV2 protein in intestine myenteric neurons}

Specificity of the anti-TRPV2 antibody was confirmed by Western blot analysis and absorption experiments in HEK293 cells expressing mouse TRPV2 (supplemental Fig. 1, available at www.jneurosci. org as supplemental material) and by absorption experiments in the immunocytochemical analysis with mouse myenteric plexus neurons (Fig. 2 B). Similar to the rat intestine (Kashiba et al., 2004), TRPV2-immunoreactive (IR) cells costained with the neuron marker PGP9.5 (Fig. 2A). Approximately half (197 of 396 neurons, $49.7 \pm 3.4 \%$, mean \pm SEM; $n=3$ mice) of the PGP9.5-IR neurons were TRPV2 positive. TRPV2 immunoreactivity was not observed in GFAP-IR 


\section{A myenteric neuron}
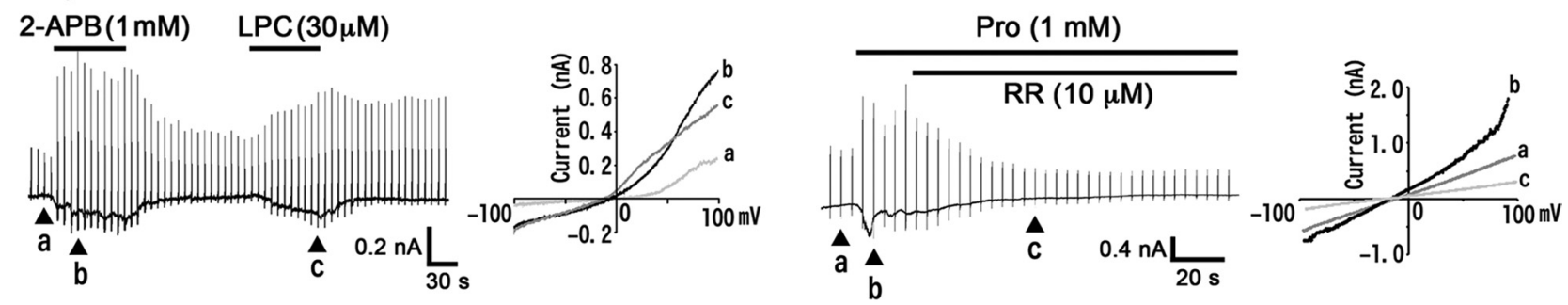

\section{B myenteric neuron}

\section{HEK293 cell}

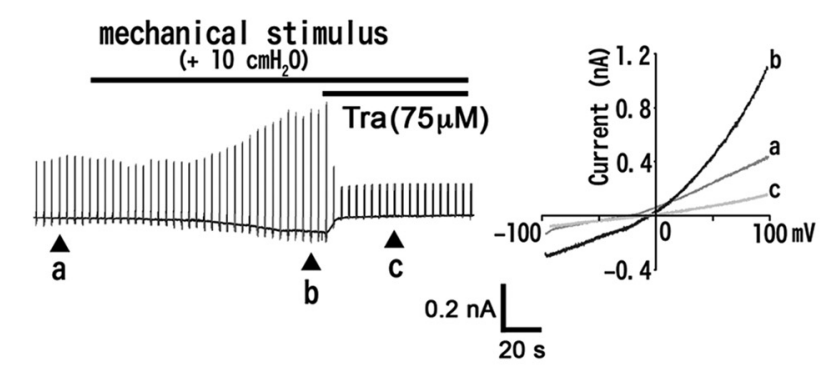

TRPV2 (+)
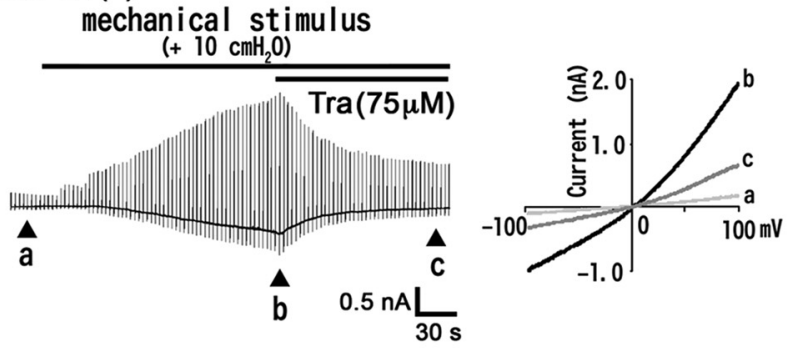

D

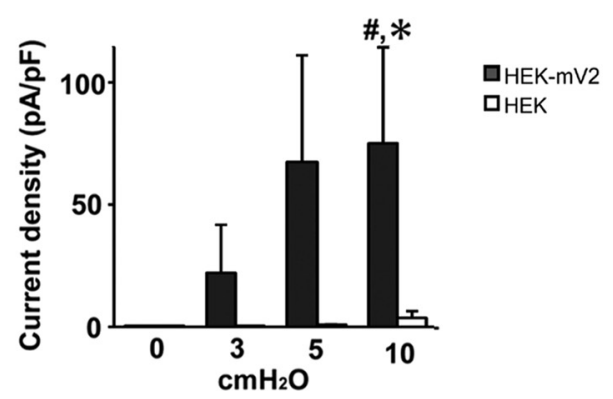

TRPV2 (-)

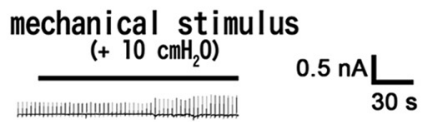

Figure 4. TRPV2 agonists-induced current responses in mouse myenteric culture neurons and TRPV2 mechanosensitivity in both native neurons and HEK293 cells. $A, 2-A P B$ ( $1 \mathrm{mM}), \mathrm{LPC}(30 \mu \mathrm{M})$, and Pro (1 mM) induced inward currents in cells held at $-60 \mathrm{mV}$ (mean \pm SEM, $127.8 \pm 34.4 \mathrm{pA}, n=9$ for $2-\mathrm{APB} ; 114.7 \pm 11.3 \mathrm{pA}, n=3$ for $\mathrm{LPC}$; and $622.6 \pm 267.7 \mathrm{pA}, n=6$ for Pro). The shown $I-V$ curves are from the indicated points $(\mathrm{a}-\mathrm{C})$ in each left trace and show outward rectification. RR $(10 \mu \mathrm{m})$ inhibited Pro-evoked current responses. $\boldsymbol{B}$, Positive pressure $\left(10 \mathrm{~cm} \mathrm{H}_{2} 0\right)$ to the pipette solution also induced an inward current at $-60 \mathrm{mV}$ with an outwardly rectifying $/-V$ relation, which was blocked by $75 \mu \mathrm{m}$ Tra. Similar current responses were observed for three cells $(316.5 \pm 89.6$ pA).C Similar positive pressure-induced inward currents were blocked by Tra $(75 \mu \mathrm{m})$ in mouse TRPV2-transfected HEK 293 cells. Similar current responses were observed in 5 of 10 cells $(75.2 \pm 39.1$ $\mathrm{pA} / \mathrm{pF}$ ) but not in 13 nontransfected HEK293 cells ( $3.7 \pm 2.8 \mathrm{pA} / \mathrm{pF}$ ). $\boldsymbol{D}$, Current densities for 3,5 , and $10 \mathrm{~cm} \mathrm{H}_{2} 0$ pressure-induced responses in mouse TRPV2-transfected HEK293 cells were $21.9 \pm$ $19.8(n=7), 67.2 \pm 43.8(n=9)$, and $75.2 \pm 39.1(n=10) \mathrm{pA} / \mathrm{pF}$, respectively. Pressure-induced TRPV2-mediated responses $\left(10 \mathrm{~cm} \mathrm{H}_{2} 0\right)$ were significantly larger than those in $0 \mathrm{~cm} \mathrm{H}_{2} \mathrm{O}$ pressure-induced responses in TRPV2-expressing cells $\left({ }^{\#} p<0.05\right)$ and than those in $10 \mathrm{~cm} \mathrm{H}_{2} 0$ pressure-induced responses in cells not expressing TRPV2 $\left({ }^{*} p<0.05\right)$.

enteroglia or KIT-IR interstitial cells of Cajal (Fig. 2C,D). Expression of several neural subtype markers was examined to determine which neurons expressed TRPV2. Some TRPV2-IR neurons costained with an anti-nNOS antibody (Fig. 2E) and most nNOS-IR neurons (606 of 682 neurons, $88.9 \pm 0.9 \%$, mean \pm SEM; $n=3$ mice) were TRPV2 positive.

It has been reported that $79.3 \%$ of nNOS-IR neurons are inhibitory circular muscle motor neurons, $10.3 \%$ are inhibitory longitudinal muscle motor neurons, and $10.3 \%$ are descending interneurons (Qu et al., 2008). Thus, it is likely that the majority of the nNOS-IR neurons observed in our study were inhibitory circular muscle motor neurons, whereas the TRPV2-negative nNOS-IR neurons may be descending interneurons. To test whether TRPV2-IR, nNOS-negative neurons (Fig. 2E) could be regarded as IPANs, we performed double staining for TRPV2 and IPAN markers CGRP or neurofilament 145 (NF145) in the mouse myenteric plexus (Qu et al., 2008) (Fig. 2F,G). Most TRPV2-IR neurons costained with CGRP and NF145, whereas $\sim 80 \%$ of CGRP-IR neurons (245 of 296 neurons, $82.4 \pm 5.2 \%$, mean \pm SEM; $n=3$ mice) and NF145-IR neurons (103 of 129 neurons, $81.0 \pm 3.8 \%$, mean \pm SEM; $n=3$ mice) were TRPV2 positive. This suggested that TRPV2-IR neurons were inhibitory motor neurons (nNOS positive) or IPANs (CGRP or NF145 positive). When nNOS- and/or TRPV2-positive neurons in the area of plexus (Fig. $2 \mathrm{H}$, left) and periphery (Fig. $2 \mathrm{H}$, right) were examined carefully, again almost all the nNOS-positive neurons expressed TRPV2, and TRPV2-IR was observed on the nerve fibers that probably covered muscle tissue.

\section{TRPV2-mediated cytosolic $\mathrm{Ca}^{2+}$ increase in intestinal} inhibitory motor neurons

To confirm functional TRPV2 expression in myenteric neurons, we examined the response to reported TRPV2 agonists (2-APB, probenecid and LPC) (Hu et al., 2004; Bang et al., 2007; Monet et al., 2009) in isolated myenteric neurons using a fluorescent $\mathrm{Ca}^{2+}$-imaging system (10 $\mu \mathrm{M}$ fura-2 AM). Representative pseudocolor images and typical ratio traces are shown in Figure 3, $A$ and $B$. All three agonists increased intracellular $\mathrm{Ca}^{2+}$ concentrations $\left(\left[\mathrm{Ca}^{2+}\right]_{\mathrm{i}}\right)$, which suggested that TRPV2 is functionally expressed in myenteric neurons. In addition, the finding that 
A $\operatorname{Pro}(\mu \mathrm{M})$

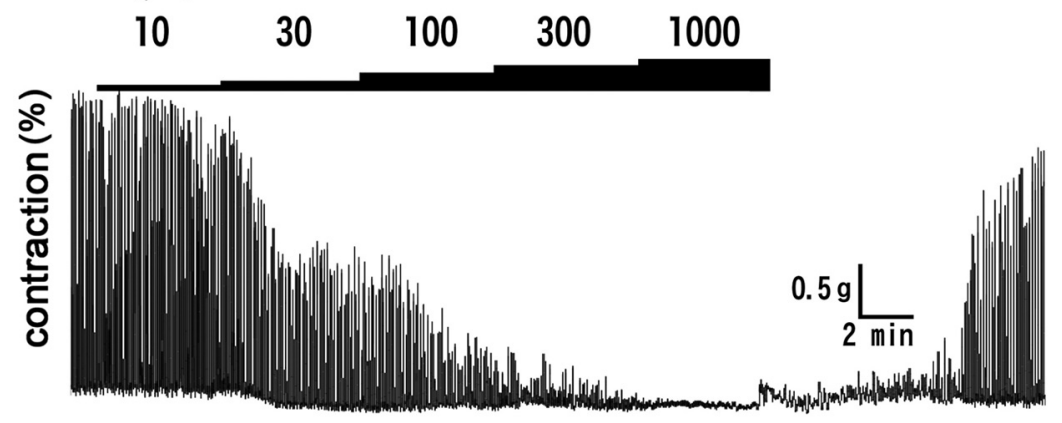

B

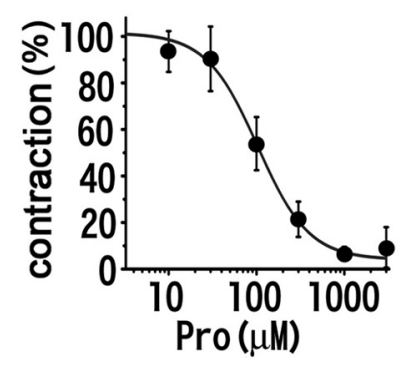

C

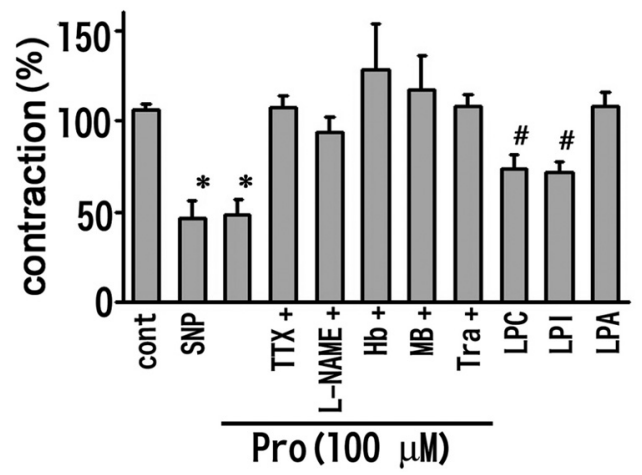

Figure 5. TRPV2 is involved in the inhibition of spontaneous circular muscle contraction. $A, A$ representative trace of dosedependent Pro-induced inhibition of spontaneous contractions of mouse intestinal circular muscle. $\boldsymbol{B}$, Dose-dependent curve for Pro-induced inhibition with an $\mathrm{IC}_{50}$ value of $95.4 \mu \mathrm{M}(n=6-17$ for each concentration). Data are presented as mean $\pm \operatorname{SEM}(n=$ $6-17)$. C, Relative mean contractions normalized to basal values. SNP $(10 \mu \mathrm{m})$ caused relaxation $(46.3 \pm 8.7 \%, n=6)$. Pro $(100 \mu \mathrm{M})$-induced inhibition ( $48.2 \pm 8.7 \%$ contraction, $n=8)$ was significantly $\left({ }^{*} p<0.05\right)$ reversed by $\operatorname{TTX}(1 \mu \mathrm{M}$, $107.2 \pm 6.8 \%, n=10)$, L-NAME $(100 \mu \mathrm{m}, 94.1 \pm 8.2 \%, n=13), \mathrm{Hb}(2 \mathrm{~mm}, 128.2 \pm 26.1 \%, n=10)$, methylene blue $(\mathrm{MB} ; 10 \mathrm{~mm}, 117.3 \pm 18.7 \%, n=9)$, and Tra $(75 \mu \mathrm{m}, 108.6 \pm 5.9 \%, n=8)$. LPC $(10 \mu \mathrm{m}, 73.4 \pm 8.1 \%, n=12)$ and $\mathrm{LPI}$ $(10 \mu \mathrm{M}, 71.0 \pm 6.4 \%, n=6)$, but not LPA $(10 \mu \mathrm{M}, 108.2 \pm 7.2 \%, n=9)$, inhibited the spontaneous contractions similar to Pro ( ${ }^{\#} p<0.05$ vs control and LPA).

LPC-induced $\left[\mathrm{Ca}^{2+}\right]_{\mathrm{i}}$ increase was abolished in the absence of extracellular $\mathrm{Ca}^{2+}\left[\mathrm{Ca}^{2+}(-)\right]$ suggested that the $\left[\mathrm{Ca}^{2+}\right]_{\mathrm{i}}$ increase was caused by $\mathrm{Ca}^{2+}$ influx through the plasma membrane. Figure $3 C$ shows that both RR, a broad TRP channel inhibitor (10 $\mu \mathrm{M})$, and $\operatorname{Tra}(75 \mu \mathrm{M})$, reported to inhibit TRPV2-mediated responses (Hisanaga et al., 2009), inhibited the LPC-induced $\left[\mathrm{Ca}^{2+}\right]_{\mathrm{i}}$ increase, further supporting TRPV2 involvement. LPC-sensitive cells (as defined in Materials and Methods) were significantly reduced in the absence of $\mathrm{Ca}^{2+}(-)$ or by $\mathrm{RR}$ or Tra treatment (Fig. 3D). Pro, another TRPV2 agonist, also increased responder rates in a dose-dependent manner, and Pro-induced responses were significantly reduced by Tra pretreatment (Fig. $3 D)$. In addition, 2 -APB increased $\left[\mathrm{Ca}^{2+}\right]_{\mathrm{i}}$ in $33.2 \%$ of the examined cells. Together, we concluded that TRPV2 is involved in the LPC-, Pro-, or 2-APB-induced $\left[\mathrm{Ca}^{2+}\right]_{\mathrm{i}}$ increase.

TRPV2 was expressed in either inhibitory motor neurons or IPANs (Fig. 2). To more effectively detect TRPV2-positive cells, we used ChAT-eGFP mice that express GFP mainly in IPANs or excitatory motor neurons (Tallini et al., 2006; Qu et al., 2008). When we compared 2-APB responses in myenteric neurons with and without GFP expression, the rates of 2-APB-sensitive cells were significantly larger in GFP-negative cells than in GFPpositive cells, which suggested that TRPV2 functions mainly in GFP-negative inhibitory motor neurons (Fig. 3E). To further explore the involvement of endogenous TRPV2 in the $\left[\mathrm{Ca}^{2+}\right]_{\mathrm{i}}$ in- creases observed above, we examined the effects of DN-TRPV2 that drastically reduces TRPV2 function in myenteric neurons (Nagasawa et al., 2007; Shibasaki et al., 2010). Using ChAT-eGFP-negative myenteric neurons, Pro-induced $\left[\mathrm{Ca}^{2+}\right]_{\mathrm{i}}$ increases were reduced in DN-TRPV2expressing cells, whereas Pro-responder rates were significantly smaller in DNTRPV2-expressing cells than in cells transfected with pcDNA3.1 alone (Fig. $3 F, G)$. This supported the involvement of endogenous TRPV2 in the $\left[\mathrm{Ca}^{2+}\right]_{i}$ increases.

TRPV2-mediated current responses in intestinal inhibitory motor neurons We next performed patch-clamp experiments with ChAT-eGFP-negative myenteric neurons to further confirm functional TRPV2 expression in intestinal inhibitory motor neurons. Both 2-APB (1 $\mathrm{mM})$ and LPC $(30 \mu \mathrm{M})$ evoked inward currents at $-60 \mathrm{mV}$, showing an outwardly rectifying $I-V$ relationship (Fig. $4 A)$. In addition, Pro ( $1 \mathrm{~mm}$ ) also caused activation of inward currents with a similar $I-V$ relationship, which were blocked by RR $(10 \mu \mathrm{M})$. These patch-clamp experiment results were consistent with the $\mathrm{Ca}^{2+}$-imaging results (Fig. 3). Mechanical stimulus with $10 \mathrm{~cm} \mathrm{H}_{2} \mathrm{O}$ pressure evoked an inward current activation with an outwardly rectifying $I-V$ relationship, which was inhibited by Tra $(75 \mu \mathrm{M})$ (Fig. $4 B)$. Similar mechanical stimulus $(10 \mathrm{~cm}$ $\mathrm{H}_{2} \mathrm{O}$ pressure)-evoked current responses with outward rectification were observed in HEK293 cells expressing mouse TRPV2 [TRPV2(+)] but not in nontransfected HEK293 cells [TRPV2(-)] (Fig. 4C), which indicated that mechanical stimulus-evoked responses required TRPV2 expression. Positive pressure stimulus did not affect cell size (expressed by cell capacitance) (supplemental Fig. 2, available at www.jneurosci.org as supplemental material). TRPV2-mediated currents became larger as pressures increased (Fig. 4D). Negative pressure also evoked TRPV2-mediated current responses (data not shown). Even $3 \mathrm{~cm} \mathrm{H} \mathrm{H}_{2} \mathrm{O}$ pressure evoked TRPV2-mediated current responses, although it was not statistically significant, which suggested that enteric neurons expressing TRPV2 could respond to weak intestinal distortion in vivo.

Relaxation of mouse intestine in response to TRPV2 agonists and its blockade by the TRPV2 antagonist TTX or NOS pathway inhibitors

The above results suggested TRPV2 involvement in intestinal function, especially relaxation. To examine this possibility, we measured spontaneous contractions of the circular muscle, using an isometric transducer. System reliability was confirmed using ACh and SNP that caused a contraction and a prolonged relaxation, respectively, as measured by changes in the height of the spontaneous basal contractions (supplemental Fig. 3, available at www.jneurosci.org as supplemental material). Pro (10 $\mu \mathrm{M}$ to $3 \mathrm{~mm}$ ) treatment of mouse intestine preparations caused 

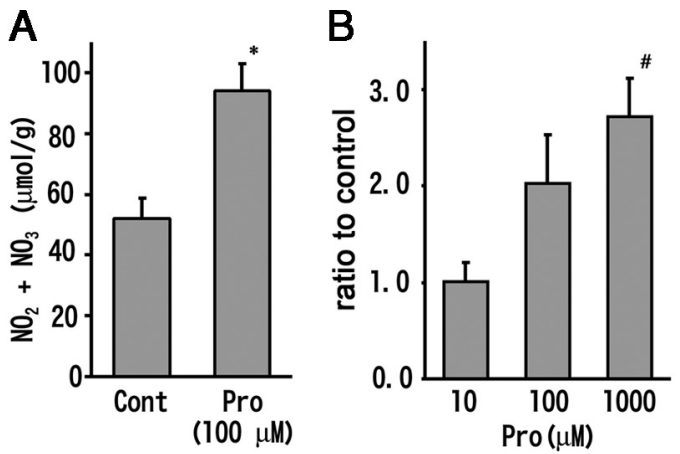

Figure 6. Increased NO production in whole intestine by probenecid. $A, N 0$ production was significantly increased in the intestine in response to $\operatorname{Pro}(100 \mu \mathrm{m}, 93.9 \pm 9.0 \mu \mathrm{mol} / \mathrm{g}, n=10)$ compared with no treatment $\left(51.9 \pm 6.8 \mu \mathrm{mol} / \mathrm{g}, n=10,{ }^{*} p<0.05\right)$. $\boldsymbol{B}$, Pro-induced increase in N0 production was dose dependent $(1.0 \pm 0.2, n=40 ; 2.0 \pm 0.5, n=31$; and $2.7 \pm$ $0.4, n=27$ for 10, 100, and $1000 \mu \mathrm{m}$, respectively). Data are expressed as mean \pm SEM after normalization to baseline values. ${ }^{\#} p<0.05$ versus Pro (10 $\left.\mu \mathrm{m}\right)$.

concentration-dependent relaxation, with a half-inhibition concentration $\left(\mathrm{IC}_{50}\right)$ value of $95.4 \pm 27.2 \mu \mathrm{M}$, that recovered after washout (Fig. $5 A, B$ ). Pro at $100 \mu \mathrm{M}$ caused $48.2 \pm 8.7 \%$ relaxation, a value similar to that obtained using SNP $(10 \mu \mathrm{M}$, $46.3 \pm 8.7 \%$ ) (Fig. 5C). Pro-induced relaxation was significantly inhibited by TTX $(1 \mu \mathrm{M})$, which indicated involvement of neural activity in the relaxation. After pretreatment with several NO pathway inhibitors (100 $\mu \mathrm{M} \mathrm{L}-\mathrm{NAME}, 2 \mathrm{mM} \mathrm{Hb}$, or $10 \mathrm{~mm}$ methylene blue), Pro did not cause significant relaxation (Fig. 5C), which suggested that the NO pathway was involved in Pro-induced relaxation, which is supported by a similar effect obtained using the NOS inhibitor L-NNA (data not shown). Pro-induced relaxation was also inhibited by Tra $(75 \mu \mathrm{M})$ (Fig. $5 C$ ). Furthermore, TRPV2 activators LPC (10 $\mu \mathrm{M})$ and LPI (10 $\mu \mathrm{M})$ (Monet et al., 2009) also inhibited spontaneous contractions. In contrast, LPA $(10 \mu \mathrm{M})$, a related compound that does not activate TRPV2, did not cause significant relaxation (Fig. 5C), consistent with a role for TRPV2 activation in relaxation.

\section{Effects of probenecid on intestinal NO release}

Given the apparent involvement of TRPV2 in NO-mediated intestinal relaxation, we examined NO production from small intestinal specimens stimulated by a TRPV2 agonist by the Griess reaction. As shown in Figure 6, $A$ and $B$, supernatant $\mathrm{NO}_{2}+\mathrm{NO}_{3}$ levels significantly increased from basal values $(51.9 \pm 6.8$ $\mu \mathrm{mol} / \mathrm{g})$ to $93.9 \pm 9.0 \mu \mathrm{mol} / \mathrm{g}$ after $30 \mathrm{~min}$ Pro $(100 \mu \mathrm{M})$ stimulation in a dose-dependent manner. This suggested that TRPV2 activation causes $\mathrm{NO}$ production, probably through $\mathrm{Ca}^{2+}$ influx.

\section{Effects of intragastric TRPV2 agonists on gastrointestinal tract transit}

Finally, to evaluate possible TRPV2-mediated regulation of intestinal transit in vivo, we examined dye movement attributable to peristaltic propulsion (coordinated intestinal contraction and relaxation). Dye concentrations at the distal intestine (Fig. 7A, arrow) were used as a measure of transit speed. Significantly higher dye concentrations were observed after intragastric administration of TRPV2 agonists ( $1 \mathrm{~mm}$ Pro and $10 \mu \mathrm{M}$ LPC) but not after LPA $(10 \mu \mathrm{M})$ (Fig. $7 B)$. Furthermore, the Pro-induced increase in dye concentration was blocked by coadministration of Tra (75 $\mu \mathrm{M})$. Together with the finding that intragastric SNP administration also accelerated intestinal movement (Fig. $7 B$ ), our results
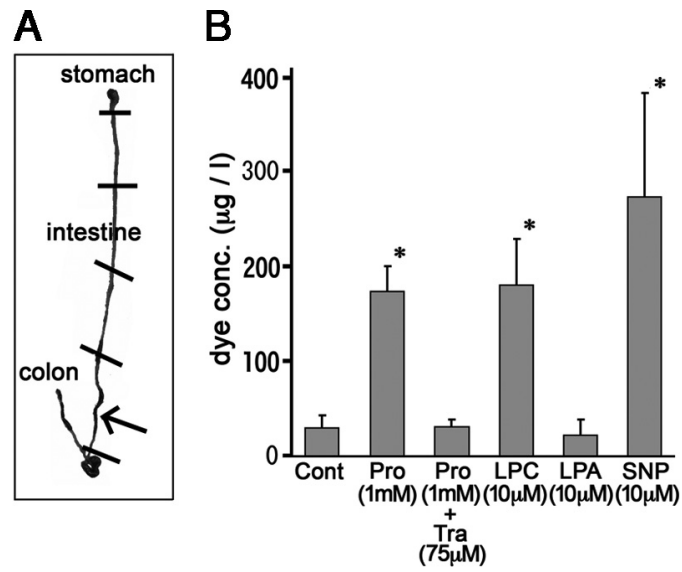

Figure 7. Increased gastrointestinal transit by TRPV2 agonists and SNP. A, Mouse small intestine was divided into four segments (shown by black bars), and dye concentrations in the fourth segment (shown as an arrow) were measured. $\boldsymbol{B}$, Dye concentrations in mice treated with Pro $(1 \mathrm{~mm}, 174.1 \pm 26.5 \mu \mathrm{g} / \mathrm{L}, n=8)$ were significantly higher $\left({ }^{*} p<0.05\right)$ than in mice without treatment $(29.7 \pm 13.0 \mu \mathrm{g} / \mathrm{L}, n=10)$. Tra $(75 \mu \mathrm{m})$ treatment abolished the Proinduced increase in dye concentration $(31.2 \pm 7.6 \mu \mathrm{g} / \mathrm{L}, n=7)$. LPC (10 $\mu \mathrm{m}, 180.1 \pm 49.8$ $\mu \mathrm{g} / \mathrm{L}, n=5)$, but not LPA $(10 \mu \mathrm{m}, 22.3 \pm 16.7 \mu \mathrm{g} / \mathrm{L}, n=5)$, significantly $\left({ }^{*} p<0.05\right)$ increased dye concentration. SNP $(10 \mu \mathrm{M})$ showed similar effects $(273.5 \pm 109.8 \mu \mathrm{g} / \mathrm{L}, n=5$, $\left.{ }^{*} p<0.05\right)$. Values are mean $\pm \mathrm{SEM}, n=5-10$.

suggested that TRPV2 accelerates intestinal movement through NO production.

\section{Discussion}

We identified anatomical and functional TRPV2 expression in murine intestinal myenteric neurons, especially in inhibitory motor neurons and/or IPANs (Figs. 1-4). TRPV2 activation induced intestinal relaxation through $\mathrm{NO}$ production, probably via cytosolic $\mathrm{Ca}^{2+}$ increase, leading to gut transit acceleration (Figs. 5-7). Our results strongly suggested that both inhibitory motor neurons and IPANs were involved in the observed TRPV2mediated peristaltic propulsion, although we cannot rule out the involvement of TRPV2 expressed in the sensory neurons whose cell bodies are located in the nodose ganglion. Because probenecid did not increase contraction in the presence of L-NAME (Fig. $5 C$ ) or L-NNA, IPAN involvement is unlikely, suggesting instead the predominant involvement of inhibitory motor neurons. Additional experiments are needed to determine to what extent TRPV2-expressing IPANs are involved in the regulation of intestinal movement. In addition, L-NAME did not completely reverse TRPV2-induced inhibition of contraction (Fig. 5C), which suggests the existence of other inhibitory neurotransmitters. Indeed, other inhibitory neurotransmitters, such as ATP, vasoactive intestinal polypeptide, $\beta$-nicotinamide adenine dinucleotide, hydrogen sulfide, and carbon monoxide, have been reported (Burnstock et al., 1970; Fahrenkrug et al., 1979; Miller et al., 2001; MutafovaYambolieva et al., 2007; Linden et al., 2008).

In the present study, intestinal relaxation caused accelerated gut transit (Figs. 5, 7). Enterochromaffin cells are believed to sense mechanical stretch, leading to IPAN activation followed by enhanced inhibitory motor neuron activity in the aboral regions. TRPV2mediated NO release from inhibitory motor neurons could support this mechanism to increase transit. The link between TRPV2 activation and NO release in intestinal movement was supported by the finding that SNP alone accelerated intestinal transit (Fig. 7B).

In our study, we used a mechanical stimulus to activate TRPV2, because TRPV2 has been shown to be mechanosensitive in cardiac myocytes and in sensory and spinal motor neurons 
(Muraki et al., 2003; Shibasaki et al., 2010). Indeed, many IPANs and some uniaxonal neurons are also reported to be mechanosensitive and activated by muscle contractions in guinea pig intestine (Kunze et al., 1998, 1999). Mechanosensitive channels in IPANs and some uniaxonal neurons appear to be $\mathrm{Gd}^{2+}$ insensitive and not pure $\mathrm{Ca}^{2+}$ channels (Furness et al., 2004b), properties similar to those of TRPV2 channels. In addition, the distribution of the reported mechanosensitive channels matches the distribution of TRPV2 observed in this study. The finding that TRPV2 expression with nNOS immunoreactivity was observed not only in the plexus but also in the nerve fibers probably covering muscle layers (Fig. 2) suggests a model in which inhibitory motor neurons, especially nerve fibers, expressing TRPV2 directly detect muscle distortion and then release NO for intestinal relaxation at the site of mechanical stimulus. Basal amounts of $\mathrm{NO}_{2}+\mathrm{NO}_{3}$ (Fig. 6) suggested continuous basal NO release, although the physiological significance of this is unknown. Basal activation of TRPV2 by endogenous mechanical stimulus could cause NO release via $\mathrm{Ca}^{2+}$ influx, leading to regulation of intestinal movement by inhibiting overaction. Luminal extension with food in the intestine might then activate TRPV2 mechanically followed by aboral intestinal relaxation. These mechanisms could play pivotal roles in intestinal relaxation in concert with the enterochromaffin cell-mediated pathway.

In addition to mechanical stimulus, TRPV2 has several known chemical activators, including endogenous lysophospholipids LPC and LPI that cause relaxation (Fig. 5C) and enhance transit (Fig. 7B) after TRPV2 activation in myenteric neurons (Figs. 3, 4A). LPC is a major phospholipid component of atherogenic oxidized low density lipoprotein and is present (micromolar range) in some tissues (Okita et al., 1997; Ishii et al., 2004). Therefore, it is tempting to speculate that TRPV2 could be activated by both mechanical and chemical stimuli synergistically to regulate intestinal contractions in physiological and pathological conditions.

Because NO is a major inhibitory neurotransmitter and its abnormal production and release may be involved in functional gastrointestinal disorders (Takahashi, 2003), development of compounds acting on TRPV2 channels could be useful.

\section{References}

Bang S, Kim KY, Yoo S, Lee SH, Hwang SW (2007) Transient receptor potential V2 expressed in sensory neurons is activated by probenecid. Neurosci Lett 425:120-125.

Bian X, Galligan JJ (2007) Alpha2-adrenoceptors couple to inhibition of R-type calcium currents in myenteric neurons. Neurogastroenterol Motil 19:845-855.

Boudaka A, Wörl J, Shiina T, Shimizu Y, Takewaki T, Neuhuber WL (2009) Galanin modulates vagally induced contractions in the mouse oesophagus. Neurogastroenterol Motil 21:180-188.

Burnstock G, Campbell G, Satchell D, Smythe A (1970) Evidence that adenosine triphosphate or a related nucleotide is the transmitter substance released by non-adrenergic inhibitory nerves in the gut. Br J Pharmacol 40:668-688.

Caprodossi S, Lucciarini R, Amantini C, Nabissi M, Canesin G, Ballarini P, Di Spilimbergo A, Cardarelli MA, Servi L, Mammana G, Santoni G (2008) Transient receptor potential vanilloid type 2 (TRPV2) expression in normal urothelium and in urothelial carcinoma of human bladder: correlation with the pathologic stage. Eur Urol 54:612-620.

Caterina MJ, Rosen TA, Tominaga M, Brake AJ, Julius D (1999) A capsaicin-receptor homologue with a high threshold for noxious heat. Nature 398:436-441.

Fahrenkrug J, Schaffalitzky de Muckadell OB, Holst JJ, Jensen SL (1979) Vasoactive intestinal polypeptide in vagally mediated pancreatic secretion of fluid and HCO3. Am J Physiol 237:E535-E540.

Firpo MA, Rollins MD, Szabo A, Gull JD, Jackson JD, Shao Y, Glasgow RE,
Mulvihill SJ (2005) A conscious mouse model of gastric ileus using clinically relevant endpoints. BMC Gastroenterol 5:18.

Furness JB (2008) The enteric nervous system: normal functions and enteric neuropathies. Neurogastroenterol Motil 20 [Suppl 1]:32-38.

Furness JB, Jones C, Nurgali K, Clerc N (2004a) Intrinsic primary afferent neurons and nerve circuits within the intestine. Prog Neurobiol 72:143-164.

Furness JB, Kearney K, Robbins HL, Hunne B, Selmer IS, Neylon CB, Chen MX, Tjandra JJ (2004b) Intermediate conductance potassium (IK) channels occur in human enteric neurons. Auton Neurosci 112:93-97.

Harrison JS, McSwiney BA (1936) The chemical transmitter of motor impulses to the stomach. J Physiol 87:79-86.

Hisanaga E, Nagasawa M, Ueki K, Kulkarni RN, Mori M, Kojima I (2009) Regulation of calcium-permeable TRPV2 channel by insulin in pancreatic beta-cells. Diabetes 58:174-184.

Hu HZ, Gu Q, Wang C, Colton CK, Tang J, Kinoshita-Kawada M, Lee LY, Wood JD, Zhu MX (2004) 2-aminoethoxydiphenyl borate is a common activator of TRPV1, TRPV2, and TRPV3. J Biol Chem 279:35741-35748.

Ichikawa H, Sugimoto T (2001) VRL-1 immunoreactivity in the rat cranial autonomic ganglia. Neuroreport 12:1597-1599.

Inada H, Iida T, Tominaga M (2006) Different expression patterns of TRP genes in murine B and T lymphocytes. Biochem Biophys Res Commun 350:762-767.

Ishii I, Fukushima N, Ye X, Chun J (2004) Lysophospholipid receptors: signaling and biology. Annu Rev Biochem 73:321-354.

Kashiba H, Uchida Y, Takeda D, Nishigori A, Ueda Y, Kuribayashi K, Ohshima M (2004) TRPV2-immunoreactive intrinsic neurons in the rat intestine. Neurosci Lett 366:193-196.

Korenaga K, Micci MA, Taglialatela G, Pasricha PJ (2006) Suppression of nNOS expression in rat enteric neurones by the receptor for advanced glycation end-products. Neurogastroenterol Motil 18:392-400.

Kunze WA, Furness JB, Bertrand PP, Bornstein JC (1998) Intracellular recording from myenteric neurons of the guinea-pig ileum that respond to stretch. J Physiol 506:827-842.

Kunze WA, Clerc N, Bertrand PP, Furness JB (1999) Contractile activity in intestinal muscle evokes action potential discharge in guinea-pig myenteric neurons. J Physiol 517:547-561.

Lewinter RD, Skinner K, Julius D, Basbaum AI (2004) Immunoreactive TRPV-2 (VRL-1), a capsaicin receptor homolog, in the spinal cord of the rat. J Comp Neurol 470:400-408.

Lewinter RD, Scherrer G, Basbaum AI (2008) Dense transient receptor potential cation channel, vanilloid family, type 2 (TRPV2) immunoreactivity defines a subset of motoneurons in the dorsal lateral nucleus of the spinal cord, the nucleus ambiguus and the trigeminal motor nucleus in rat. Neuroscience 151:164-173.

Linden DR, Sha L, Mazzone A, Stoltz GJ, Bernard CE, Furne JK, Levitt MD, Farrugia G, Szurszewski JH (2008) Production of the gaseous signal molecule hydrogen sulfide in mouse tissues. J Neurochem 106:15771585.

Link TM, Park U, Vonakis BM, Raben DM, Soloski MJ, Caterina MJ (2010) TRPV2 has a pivotal role in macrophage particle binding and phagocytosis. Nat Immunol 11:232-239.

Miller SM, Reed D, Sarr MG, Farrugia G, Szurszewski JH (2001) Haem oxygenase in enteric nervous system of human stomach and jejunum and co-localization with nitric oxide synthase. Neurogastroenterol Motil 13:121-131.

Monet M, Gkika D, Lehen'kyi V, Pourtier A, Vanden Abeele F, Bidaux G, Juvin V, Rassendren F, Humez S, Prevarsakaya N (2009) Lysophospholipids stimulate prostate cancer cell migration via TRPV2 channel activation. Biochim Biophys Acta 1793:528-539.

Monet M, Lehen'kyi V, Gackiere F, Firlej V, Vandenberghe M, Roudbaraki M, Gkika D, Pourtier A, Bidaux G, Slomianny C, Delcourt P, Rassendren F, Bergerat JP, Ceraline J, Cabon F, Humez S, Prevarskaya N (2010) Role of cationic channel TRPV2 in promoting prostate cancer migration and progression to androgen resistance. Cancer Res 70:1225-1235.

Muraki K, Iwata Y, Katanosaka Y, Ito T, Ohya S, Shigekawa M, Imaizumi Y (2003) TRPV2 is a component of osmotically sensitive cation channels in murine aortic myocytes. Circ Res 93:829-838.

Mutafova-Yambolieva VN, Hwang SJ, Hao X, Chen H, Zhu MX, Wood JD, Ward SM, Sanders KM (2007) Beta-nicotinamide adenine dinucleotide is an inhibitory neurotransmitter in visceral smooth muscle. Proc Natl Acad Sci U S A 104:16359-16364. 
Nagasawa M, Nakagawa Y, Tanaka S, Kojima I (2007) Chemotactic peptide fMetLeuPhe induces translocation of the TRPV2 channel in macrophages. J Cell Physiol 210:692-702.

Nozawa K, Kawabata-Shoda E, Doihara H, Kojima R, Okada H, Mochizuki S, Sano Y, Inamura K, Matsushime H, Koizumi T, Yokoyama T, Ito H (2009) TRPA1 regulates gastrointestinal motility through serotonin release from enterochromaffin cells. Proc Natl Acad Sci U S A 106:34083413.

Okita M, Gaudette DC, Mills GB, Holub BJ (1997) Elevated levels and altered fatty acid composition of plasma lysophosphatidylcholine (lysoPC) in ovarian cancer patients. Int J Cancer 71:31-34.

Patel BA, Galligan JJ, Swain GM, Bian X (2008) Electrochemical monitoring of nitric oxide released by myenteric neurons of the guinea pig ileum. Neurogastroenterol Motil 20:1243-1250.

Penuelas A, Tashima K, Tsuchiya S, Matsumoto K, Nakamura T, Horie S, Yano S (2007) Contractile effect of TRPA1 receptor agonists in the isolated mouse intestine. Eur J Pharmacol 576:143-150.

Qu ZD, Thacker M, Castelucci P, Bagyánszki M, Epstein ML, Furness JB (2008) Immunohistochemical analysis of neuron types in the mouse small intestine. Cell Tissue Res 334:147-161.

Rand MJ (1992) Nitrergic transmission: nitric oxide as a mediator of nonadrenergic, non-cholinergic neuro-effector transmission. Clin Exp Pharmacol Physiol 19:147-169.
Shibasaki K, Murayama N, Ono K, Ishizaki Y, Tominaga M (2010) TRPV2 enhances axon outgrowth through its activation by membrane stretch in developing sensory and motor neurons. J Neurosci 30:4601-4612.

Takahashi T (2003) Pathophysiological significance of neuronal nitric oxide synthase in the gastrointestinal tract. J Gastroenterol 38:421-430.

Tallini YN, Shui B, Greene KS, Deng KY, Doran R, Fisher PJ, Zipfel W, Kotlikoff MI (2006) BAC transgenic mice express enhanced green fluorescent protein in central and peripheral cholinergic neurons. Physiol Genomics 27:391-397.

Ward SM, Bayguinov J, Won KJ, Grundy D, Berthoud HR (2003) Distribution of the vanilloid receptor (VR1) in the gastrointestinal tract. J Comp Neurol 465:121-135.

Wehner S, Straesser S, Vilz TO, Pantelis D, Sielecki T, de la Cruz VF, Hirner A, Kalff JC (2009) Inhibition of p38 mitogen-activated protein kinase pathway as prophylaxis of postoperative ileus in mice. Gastroenterology 136:619-629.

Williamson S, Pompolo S, Furness JB (1996) GABA and nitric oxide synthase immunoreactivities are colocalized in a subset of inhibitory motor neurons of the guinea-pig small intestine. Cell Tissue Res 284:29-37.

Zanou N, Iwata Y, Schakman O, Lebacq J, Wakabayashi S, Gailly P (2009) Essential role of TRPV2 ion channel in the sensitivity of dystrophic muscle to eccentric contractions. FEBS Lett 583:3600-3604. 